\title{
ANALISIS KETERAMPILAN MENGAJAR ASPEK MENGADAKAN VARIASI DALAM PEMBELAJARAN TEMATIK KELAS IV SD PRESTASI GLOBAL
}

\author{
${ }^{1}$ Yulida Choirunnisa, ${ }^{2}$ Robiatul Munajah \\ ${ }^{1}$ Universitas Trilogi, Jalan TMP. Kalibata No. 1, Pancoran, Jakarta 12760, (021) 7981350 \\ ${ }^{2}$ Universitas Trilogi, Jalan TMP. Kalibata No. 1, Pancoran, Jakarta 12760, (021) 7981350 \\ e-mail:yulidasaa@gmail.com,nengrobiatulmunajah@trilogi.ac.id \\ Phone number author : 08988928413, 089682773130
}

\begin{abstract}
Abstrak
Penelitian ini bertujuan untuk menggambarkan keterampilan pengajar, respon siswa terhadap guru, dan hambatan yang dialami guru dalam melaksanakan variasi pembelajaran tematik kelas IV Dahlia SD Prestasi Global. Penelitian ini memakai metode penelitian kualitatif menggunakan membuat data berupa deskriptif. Teknik pengumpulan data yang digunakan peneliti merupakan teknik pengumpulan data dengan wawancara, observasi serta dokumentasi. hasil analisis data keterampilan mengajar aspek mengadakan variasi pada pembelajaran tematik pada kelas ditemukan bahwa keterampilan mengajar pengajar pada kelas tadi telah cukup baik pada mengadakan variasi saat proses pembelajaran, terlihat respon berasal beberapa siswa saat pembelajaran berlangsung jua sudah membagikan adanya keaktifan, serta adapun kendala yang dialami pengajar yaitu terkait karakter siswa, pemahaman materi, kurang disiplin peserta didik serta siswa tidak hening ketika pembelajaran.
\end{abstract}

Kata Kunci: Keterampilan Mengajar, Variasi Mengajar, Pembelajaran Tematik

\begin{abstract}
This study aims to describe the skills of teachers, student responses to teachers, and the obstacles experienced by teachers in implementing variations of thematic learning for class IV Dahlia SD Prestasi Global. This study uses a qualitative research method using descriptive data. The data collection technique used by the researcher is a data collection technique with interviews, observations and documentation. The results of the data analysis of teaching skills aspects of conducting variations in thematic learning in the classroom found that the teaching skills of the teachers in the class were quite good at making variations during the learning process, it was seen that the responses came from several students during the learning process and had shared their activity, as well as the obstacles faced by the students. experienced by the teacher is related to the character of students, understanding of the material, lack of discipline of students and students are not silent when learning.
\end{abstract}

Keywords: Teaching Skills, Teaching Variations, Thematic Learning 


\section{PENDAHULUAN}

Pendidikan didefinisikan menjadi sektor krusial dengan yang akan terjadi yang berkualitas asal sumber daya manusia. Salah satu pilar pembangunan asal daya insan adalah kualitas pembelajaran sebagai hal terpenting pada pembangunan pendidikan nasional. Berkenaan menggunakan hal tersebut, kiprah guru sangatlah krusial pada kegiatan pembelajaran sebab guru bisa memberikan materi, berinteraksi menggunakan siswa, membimbing peserta didik, mentransfer pengetahuan secara eksklusif, dan mencapai potensi mereka.

Keterampilan variasi pembelajaran yang bekerjasama dengan kurikulum kini diperbolehkan, yaitu kurikulum 2013. pada hal pembelajaran tematik di kurikulum 2013, keterampilan dasar bagi guru sangatlah krusial. Variasi dalam mengajar yang dilakukan pengajar diantaranya: (1) menaikkan perhatian siswa di matriks; (2) menyampaikan kesempatan buat menyebarkan bakat buat hal-hal baru saat belajar; (3) menanamkan sikap belajar yang positif pada kalangan siswa; (4) menyampaikan siswa kesempatan belajar yang sinkron dengan tingkat perkembangan dan keterampilan mereka (Mulyasa, 2016).

Perhatian peserta didik belum terfokus pada guru, pengajar hanya mengajar satu metode, yaitu guru tidak melakukan perubahan apa pun. pengajar hanya memakai metode teacher center yang pembelajarannya hanya terfokus pada guru. Selama ini guru melakukan sesi tanya jawab dalam beberapa sesi, namun siswa tidak aktif menjawab pertanyaan pengajar. guru hanya sedikit melakukan gerakan tubuh, siswa tidak tahu proses pembelajaran karena pembelajaran tersebut tidak menyampaikan makna yang utuh kepada siswa. bahan ajar yang tersedia cukup banyak tetapi belum sepenuhnya digunakan pada proses pedagogi, serta pola hubungan pula tampak terus-menerus karena pengajar memakai metode pengajaran yang tidak tidak selaras menggunakan keterampilan mengajar lainnya.

Kurangnya persiapan sebelum memulai belajar dan kesamaan buat memakai cara yang sama asal saat ke saat hingga menyebabkan kebosanan serta kejenuhan di siswa. Penulis ingin mendalami dan menyelidiki pertanyaan-pertanyaan tadi dengan penelitian kualitatif ihwal keterampilan mengajar pada pembelajaran tematik pada kelas IV menggunakan topik pembahasan Tema 6 Subtema 1: saya serta Cita-Citaku menggunakan judul "Analisis Keterampilan Mengajar Aspek Mengadakan Variasi dalam Pembelajaran Tematik Kelas IV Sekolah Dasar Prestasi Global”. 


\section{METODE PENELITIAN}

Penelitian ini dilaksanakan pada bulan April 2021 sampai Mei 2021. Kawasan penelitian dilaksanakan pada Sekolah Dasar Prestasi Global Jl. Palem 1 Jl. Perumahan Mampang Indah 2 No.1, Rangkapan Jaya, Kec. Pancoran Mas, Kota Depok, Jawa Barat.

Penelitian ini menggunakan metode penelitian kualitatif untuk menghasilkan data deskriptif yang bertujuan buat mengeksplorasi serta mengevaluasi objek. Pengumpulan data melalui observasi, wawancara dan dokumentasi. akibat deskriptif berasal penelitian ini menggambarkan serta menginterpretasikan objek sesuai kejadiannya.

Peneliti akan berperan sebagai instrumen utama, yang akan melakukan proses penelitian secara langsung dalam pengamatan yang dilaksanakan dengan mewawancarai narasumber secara langsung, mengumpulkan berbagai data terkait keterampilan yang dikuasai guru serta respon siswa terhadap pembelajaran di kelas. Dengan demikian, laporan penelitian ini berisikan hasil dari catatan observasi di lapangan, wawancara dan dokumen pendukung seperti data, foto dan lainnya.

Populasi dalam penelitian ini, yaitu: guru serta siswa kelas IV Dahlia SD Prestasi Global. Adapun konsep sampel pada penelitian ialah bagian kecil dari populasi yang diambil menurut prosedur tertentu sehingga sampel ini bisa mewakili populasinya secara representatif. Berikut merupakan tabel daftar nama guru serta siswa kelas IV Dahlia yang menjadi sampel pada penelitian.

Tabel Daftar Sampel Guru Kelas IV SD Prestasi Global

\begin{tabular}{lll}
\hline No. & \multicolumn{1}{c}{ Nama Guru } & \multicolumn{1}{c}{ Kelas } \\
\hline 1. & Hadha Johanna Aryani, S.T., S.Pd & 4 Dahlia \\
& Rizalina Nur Azizah, S.Pd & \\
\hline
\end{tabular}

Tabel Daftar Sampel Siswa Kelas IV Dahlia SD Prestasi Global

\begin{tabular}{lll}
\hline No. & \multicolumn{1}{c}{ Nama Siswa } & \multicolumn{1}{c}{ Keterangan } \\
\hline $\mathbf{1}$ & Alden Alvaro Suwandi & Siswa Kelas IV Dahlia \\
\hline $\mathbf{2}$ & Alykha Shakifaeyza Mulya & Siswa Kelas IV Dahlia \\
\hline $\mathbf{3}$ & Athalla Nabil Rizki & Siswa Kelas IV Dahlia \\
\hline
\end{tabular}




\begin{tabular}{lll}
\hline $\mathbf{4}$ & Daffa Naufal Anggara & Siswa Kelas IV Dahlia \\
\hline $\mathbf{5}$ & Elsa Khairani Nurendro. P & Siswa Kelas IV Dahlia \\
\hline
\end{tabular}

Data serta teknik analisis data yang dipergunakan pada penelitian ini yaitu: sumber data primer dalam penelitian ini artinya pengajar serta peserta didik kelas IV Dahlia, serta kepala sekolah SD Prestasi Global.

Sumber data sekunder pada penelitian ini adalah dokumen pendukung penelitian berupa beberapa data sekolah, RPP, silabus, program tahunan, acara semester Sekolah Dasar Prestasi Global dan hasil dokumentasi berupa foto.

Teknik analisis data yang digunakan sang peneliti yaitu reduksi data, penyajian data, dan Penarikan konklusi/verifikasi. pemeriksaan keabsahan data yang digunakan sang peneliti yaitu ketekunan pengamatan, triangluasi dan uraian rinci dengan alur sebagai berikut:

\section{Gambar Teknik Analisis Data}

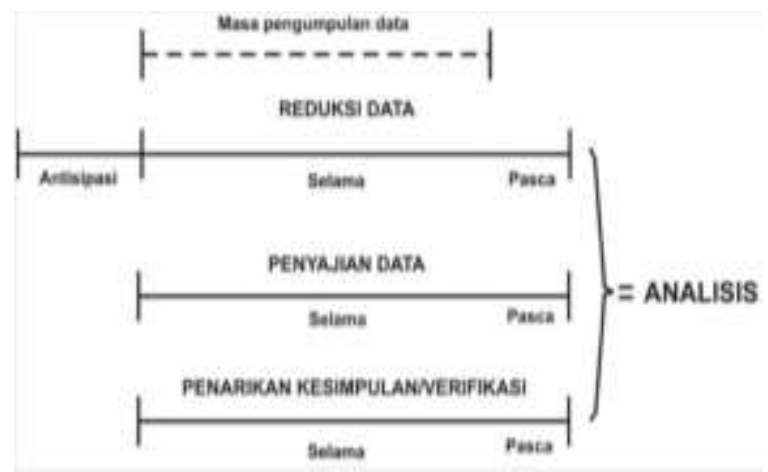

Sumber : (Sugiyono, 2018)

Sumber data dalam penelitian ini adalah subjek pengumpulan data. Data yang kemudian dijadikan acuan dalam penelitian ini berasal dari berbagai sumber data primer yaitu guru kelas IV Dahlia SD Prestasi Global tentang keterampilan mengadakan variasi pembelajaran tematik dan kendala apa saja yang dihadapi guru dalam menciptakan variasi pembelajaran di kelas. Kedua, siswa kelas IV SD Prestasi Global, untuk melihat bagaimana reaksi siswa terhadap guru ketika mereka melakukan perubahan pembelajaran di kelas. Ketiga, Kepala Sekolah Dasar Prestasi Global, yang menangani aspek kompetensi mengajar untuk melakukan berbagai pembelajaran kelas empat tematik. Serta sumber data sekunder berupa dokumen pendukung penelitian berupa beberapa data sekolah, RPP, silabus, program tahunan, program semester SD Prestasi Global serta hasil dokumentasi berupa foto. 
Hasil Penelitian kualitatif dianggap efektif bila tidak ada perbedaan antara apa yang dilaporkan oleh peneliti dengan apa yang sebenarnya terjadi apabila terdapat (1) Ketekunan pengamatan, tujuan ketekunan pengamatan adalah untuk dapat menemukan unsur-unsur situasi yang relevan dengan masalah yang sedang dipertimbangkan, yang kemudian memusatkan data lebih dekat pada masalah tersebut. (2) Triangulasi mewakili keandalan data atau validasi informasi dari berbagai sumber. Menurut Moleong, teknologi triangulasi adalah metode untuk memverifikasi keaslian informasi dengan menggunakan faktor lain. Peneliti menggunakan metode eksperimen ini untuk menguji hasil dengan membandingkannya dengan berbagai sumber, metode, dan teori. Segitiga yang digunakan dalam survei adalah penyebab dari segitiga tersebut. (3) Uraian Rinci, mewakili keandalan data atau validasi informasi dari berbagai sumber. Peneliti menggunakan metode eksperimen ini untuk menguji hasil dengan membandingkannya dengan berbagai sumber, metode, dan teori. Segitiga yang digunakan dalam survei adalah penyebab dari segitiga tersebut.

\section{HASIL DAN PEMBAHASAN}

Berikut merupakan gambaran informan yang sudah membantu peneliti pada mengumpulkan data yang diperlukan terkait keterampilan mengadakan variasi pembelajaran tematik pada kelas IV Dahlia SD Prestasi Global.

Tabel Daftar Nama Informan

\begin{tabular}{llll}
\hline No. & \multicolumn{1}{c}{ Nama } & Kode & Keterangan \\
\hline 1. & Hadha Johanna Aryani, S.T., S.Pd & HJA & Wali Kelas IV Dahlia \\
\hline 2. & Rizalina Nur Azizah, S.Pd & RNA & Guru Kelas IV Dahlia \\
\hline 3. & Alden Alvaro Suwandi & AAS & Siswa Kelas IV Dahlia \\
\hline 4. & Alykha Shakifaeyza Mulya & ASM & Siswa Kelas IV Dahlia \\
\hline 5. & Athalla Nabil Rizki & ANR & Siswa Kelas IV Dahlia \\
\hline 6. & Daffa Naufal Anggara & DNA & Siswa Kelas IV Dahlia \\
\hline 7. & Elsa Khairani Nurendro. P & EKN & Siswa Kelas IV Dahlia \\
\hline
\end{tabular}

Akibat penelitian terhadap penerapan keterampilan variasi pembelajaran tematik dilakukan di sekolah, mulai dari kelas I sampai kelas VI. Artinya hampir semua guru sudah 
familiar dengan penerapan pembelajaran tematik dan konveksi materi yang digabungkan dari setiap mata pelajaran untuk membentuk suatu topik.

Hasil penelitian terhadap penerapan keterampilan variasi pembelajaran tematik yang dilakukan oleh HJA dan RNA di kelas IV Dahlia SD Prestasi Global dapat dikatakan cukup baik. Hal tersebut didukung oleh keyakinan akan perubahan, suatu kemampuan yang harus dikembangkan guru saat pembelajaran untuk mengatasi kebosanan siswa, sehingga siswa termotivasi, dan tekun dalam belajar.

Berdasarkan pengamatan peneliti terhadap variasi pembelajaran termasuk di dalamnya prinsip-prinsip perencanaan variasi, variasi kegiatan gaya mengajar, interaksi kegiatan belajar, dan variasi penggunaan media, dapat dijabarkan yaitu:

\section{- Prinsip Perencanaan Variasi}

Perangkat pembelajaran lainnya yang telah guru siapkan diantaranya yaitu silabus, program tahunan, program semester, jurnal, absensi, buku penilaian, bank soal, dan media pembelajaran. Adapun RPP yang telah disusun guru juga sudah memuat aspek Scientific Approach. Sekolah menerapkan penyusunan RPP satu lembar yang mana di dalamnya berisi tujuan pembelajaran, kegiatan pembelajaran (kegiatan penutup, kegiatan inti dan kegiatan pembuka).

\section{- Aktivitas Variasi Gaya Mengajar}

HJA terlihat dapat memberikan jeda pada saat menyampaikan materi. Pada saat pembelajaran tersebut HJA sedang meminta siswa untuk menunjukkan soal latihan yang sudah mereka kerjakan. HJA telah menyiapkan variasi nada suara agar isi pesan yang diberikan dapat dipahami dengan jelas. Kemudian RNA juga mendorong siswa untuk fokus pada materi ajar. terkadang RNA mengingatkan siswa bahwa mereka sering sibuk saat belajar dan memberikannya kepada siswa karena tidak memperhatikan materi.

\section{- Interaksi Kegiatan Pembelajaran}

Siswa memiliki kesempatan untuk berinteraksi dengan siswa lain dan HJA memberikan umpan balik kepada siswa. Misalnya, ketika seorang guru bertanya kepada seorang siswa, ada pola interaksi guru-siswa. Hal tersebut didasari karena untuk menunjang kegiatan belajar mengajar menjadi aktif, maka dari itu diperlukan adanya komunikasi atau interaksi saat proses pembelajaran. Pola interaksi dapat terjadi antara lain yaitu: 
Indonesian Journal of Elementary Education

Vol. 3, No.1, Desember 2021

E-ISSN: 2722-6689

http://jurnal.umt.ac.id/index.php/IJOEE

\section{- Variasi Penggunaan Media Pembelajaran}

HJA dan RNA menggunakan sebagian besar media pembelajaran, namun masih ada beberapa siswa yang mengabaikan penjelasan guru. Media yang digunakan guru adalah powerpoint, demonstrasi video pembelajaran interaktif dan aplikasi quizizz yang digunakan semaksimal mungkin untuk meningkatkan pemahaman siswa terhadap materi.

\section{Gambar Variasi Penggunaan Media Pembelajaran}
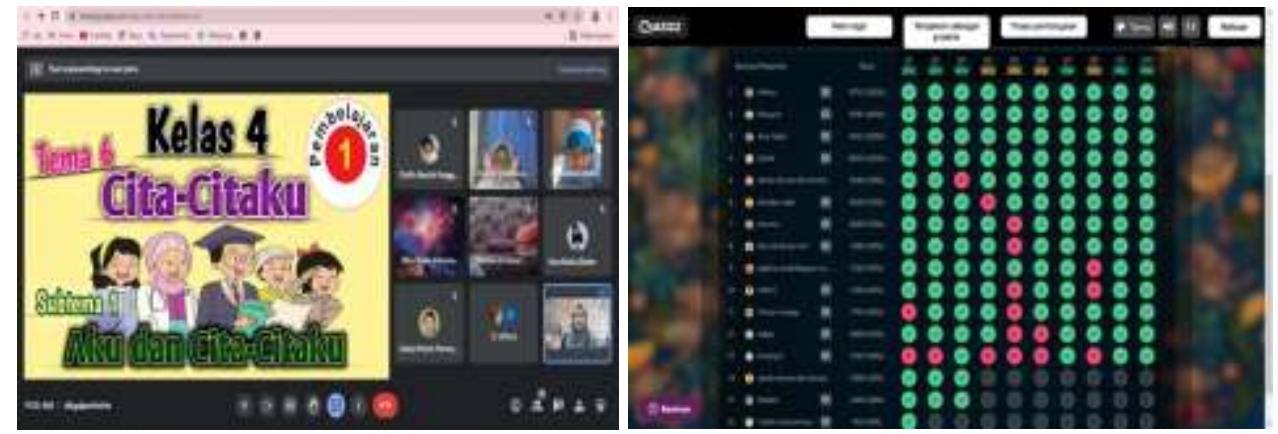

Selama proses pengajaran, respon siswa dapat mengukur keberhasilan belajar seorang guru. Hal ini didasarkan pada kenyataan bahwa guru dan siswa saling memperkuat dan mengandalkan satu sama lain untuk mencapai tujuan berbasis pembelajaran. Oleh karena itu, peneliti juga fokus memantau kegiatan kelas IV Dahlia selama kegiatan pembelajaran. Memahami kualifikasi mengajar guru mempengaruhi aktivitas belajar siswa. Adapun keaktifan yang terjadi di kelas yaitu: (1) Siswa mengkondisikan diri di dalam kelas; (2) Siswa memperhatikan penjelasan guru; (3) Siswa mengajukan pertanyaan; (4) Siswa aktif saat proses pembelajaran; (5) Siswa memanfaatkan media pembelajaran.

Kendala yang dialami Guru dalam Melaksanakan Variasi Pembelajaran Tematik di kelas IV Dahlia SD Prestasi Global yaitu termasuk dalam permasalahan yang dihadapi guru kelas IV Dahlia dalam menggunakan topik pengajaran yang berbeda, yaitu guru menghadapi kesulitan dalam beberapa hal sebagai berikut:

- Karakter siswa

Kesulitan dalam memanfaatkan perbedaan belajar terletak pada perbedaan karakter dari masing-masing siswa saat Gmeet. Ada 18 siswa di kelas, tetapi HJA dan RNA masih harus memahami karakter dari 18 siswa tersebut. HJA dan RNA perlu menemukan kesamaan untuk memfasilitasi kelancaran pembelajaran, meskipun sifat berbeda, HJA dan RNA berusaha menyatukan tindakan dan karakter setiap siswa 
- Pemahaman materi

Kurangnya pemahaman setiap siswa adalah salah satu kendala yang sering dihadapi HJA dan RNA saat pembelajaran berlangsung. Siswa kurang reseptif terhadap materi yang membuatnya sulit untuk menerima penjelasan dari HJA maupun RNA. Misalnya saat siswa diberikan sebuah pertanyaan dan juga diminta untuk memberikan contoh pada soal di buku tematik halaman 43, beberapa siswa masih memerlukan bimbingan dari HJA dan RNA. Hal tersebut dikarenakan pesan atau materi yang disampaikan oleh HJA dan RNA belum dapat dipahami dengan baik oleh beberapa siswa.

- Kurang disiplin siswa

Disiplin merupakan salah satu komponen keberhasilan belajar yang meliputi manajemen waktu dan kedisiplinan selama masa studi. Ada satu sampai dua siswa yang terlambat untuk masuk Gmeet, yang lain terlambat menjawab pertanyaan guru. Siswa berpikir dan mendengarkan selama objek saat ini dan kegiatan belajar hingga 3 menit ketika guru mengajukan pertanyaan untuk permainan dan informasi

- Tidak tenang saat pembelajaran

Jika siswa tidak nyaman di dalam kelas, mereka dapat mengganggu rencana guru saat melakukan perubahan pengajaran. Sehingga guru membutuhkan waktu ekstra untuk membuat siswa menjadi tenang dan hal tersebut juga akan membuat siswa lain yang memang tertib merasa cepat bosan karena pembelajaran belum juga dimulai. Dengan demikian maka diperlukan kesiapan guru untuk melakukan ice breaking untuk membuat siswa menjadi fokus kembali dan siap untuk menerima materi pelajaran.

Keterampilan mengajar serta variasi mengajar tematik di kelas IV Dahlia SD Prestasi Global. Masalah yang diteliti lebih lanjut dalam penelitian ini berkaitan dengan keterampilan variasi mengajar, yang menjadi inti dari penelitian ini, masalah keterampilan mengajar dalam melakukan variasi pembelajaran tematik. Penting untuk menyelidiki pertanyaan ini karena kemampuan untuk melakukan berbagai macam variasi adalah keterampilan dasar yang harus dimiliki guru. Mencapai variasi berarti mengatasi kebosanan siswa sehingga mereka antusias, bekerja keras dan terlibat penuh dalam proses pembelajaran.

Berdasarkan pengamatan yang dilakukan peneliti selama pembelajaran, sekolah diketahui telah menerapkan pembelajaran tematik dari kelas I hingga kelas VI. Namun masih 
sulit bagi guru untuk menghubungkan materi dari satu mata pelajaran dengan mata pelajaran lain dan menggabungkannya menjadi satu mata pelajaran. Secara umum HJA dan RNA sudah melakukan yang terbaik dalam memberikan pendidikan tematik.

Hal ini merupakan perpaduan antara modeling learning yang memungkinkan siswa secara aktif mengeksplorasi dan secara aktif menggali konsep dan prinsip secara menyeluruh, efektif, dan realistis, baik secara individu maupun kelompok. Selain itu, menurut Rusman, kajian mata pelajaran terkesan mendua tentang pemisahan mata pelajaran, dan topik pembahasannya menyangkut persoalan-persoalan yang berkaitan dengan kehidupan seharihari.

\section{KESIMPULAN}

Berdasarkan hasil penelitian dan pembahasan mengenai Analisis Keterampilan Mengajar Aspek Mengadakan Variasi dalam Pembelajaran Tematik Kelas IV SD Prestasi Global, dalam mengadakan variasi pembelajaran adalah salah satu keterampilan yang harus dimiliki oleh setiap guru. Kondisi yang terlihat pada saat peneliti melakukan observasi, menunjukkan bahwa guru kelas IV Dahlia telah menguasai keterampilan mengajar yaitu dalam mengadakan variasi pembelajaran dengan sangat baik. Perencanaan variasi pembelajaran dilakukan dengan berbagai macam yaitu gerak tubuh, suara, kegiatan yang meningkatkan semangat belajar, interaksi yang terjadi, dan penggunaan media pembelajaran. Pemberian variasi tersebut dapat meningkatkan keaktifan siswa serta dapat memotivasi siswa untuk belajar.

Respon siswa atau aktivitas siswa di kelas IV Dahlia SD Prestasi Global selama mengikuti kegiatan pembelajaran tematik juga dapat dikatakan baik dan mendapat respon yang positif saat guru melaksanakan keterampilan variasi mengajar. Pada awal pembelajaran siswa sudah menunjukkan kesiapannya. Dengan variasi pembelajaran yang guru terapkan, membuat siswa tampak antusias mengikuti serangkaian kegiatan pembelajaran. Siswa juga mulai mengajukan pertanyaan dan mendiskusikan berbagai topik pembelajaran

Perencanaan variasi pembelajaran di kelas IV Dahlia SD Prestasi Global masih menemui beberapa kendala, yakni kondisi latar belakang dan karakteristik siswa yang berbeda. Sehingga guru memberikan perlakuan yang bervariasi pada masing-masing siswa sesuai dengan karakteristik mereka. Selain itu, banyaknya materi pembelajaran di kelas tinggi yang 
harus dikemas dalam satu tema, membuat guru lebih fokus terhadap penyampaian materi pelajaran saja, sehingga mengabaikan pengadaan variasi pembelajaran. Dan keterbatasan fasilitas di sekolah juga menjadi kendala dalam guru mengadakan variasi pembelajaran. Variasi yang dilakukan hanya sebatas variasi pemusatan perhatian siswa.

\section{DAFTAR PUSTAKA}

Creswell, J. (2012). Research Design Pendekatan Metode Kuantitatif, Kualitatif dan R\&D. Yogyakarta: Pustaka Pelajar.

Darmadi, H. (2014). Kemampuan Dasar Mengajar. Bandung: Alfabeta.

Darmadi, H. (2014). Metode Pendelitian Pendidikan serta Sosial. Bandung: Alfabeta.

Djamarah, S. B. (2014). strategi Belajar Mengajar. Jakarta: PT Rineka Cipta.

Hasibuan, J., \& Moedjiono. (2010). Proses Belajar Mengajar. Bandung: PT Rosdakarya. Majid, A. (2014). Pembelajaran Tematik Terpadu. Bandung: PT Remaja Rosdakarya.

Marhawati, B. (2018). Pengantar supervisi Pendidikan. Yogyakarta: CV Budi primer.

Moleong, L. J. (2018). Metodologi Penelitian Kualitatif. Bandung: PT Remaja Rosdakarya.

Mulyasa, E. (2016). "Menjadi Pengajar Profesional". Bandung: PT Remaja Rosdakarya.

Rusman. (2015). Pembelajaran Tematik Terpadu: Teori, Praktik dan penilaian. Jakarta: Rajawali Pers.

Salim, D., \& Haidir, D. (2019). Penelitian Pendidikan: Metode, Pendekatan, serta Jenis. Depok: Kencana.

Sardiman. (2015). hubungan serta Motivasi Belajar. Jakarta: Grafindo.

Sugiyono. (2018). Metode Penelitian Kuantitatif, Kualitatif, dan R\&D. Bandung: Alfabeta.

Sumantri, M. (2014). taktik Belajar Mengajar. Jakarta: Departemen Pendidikan dan Kebudayaan.

Suparman. (2010). Gaya Mengajar yang Menyenangkan peserta didik. Yogyakarta: Pinus Book Publisher.

Usman, M. U. (2017). sebagai guru Profesional. Bandung: Rosdakarya.

Walgito, B. (2015). Pengantar Psikologi awam. Yogyakarta: CV Andi 